\title{
Les voix singulières d'Alexandre Amprimoz : sapientia et eloquentia
}

Kenneth MEADWELL, Université de Winnipeg

Il est des individus qui restent avec nous, même après qu'ils nous eurent quittés. Tel est le cas d'Alexandre Amprimoz, né à Rome et qui s'éteignit le 12 octobre 2012 à l'âge de 64 ans. Ses voix singulières résonnent encore : celle de l'érudit, celle du poète et de l'auteur de nouvelles, celle du traducteur, celle du mathématicien et informaticien, celle de l'ami, celle du pédagogue, celle du collègue. Celle aussi du «maître », comme je l'appelais au cours de sa direction de ma thèse de doctorat sur l'œuvre romanesque de Réjean Ducharme. Nul ne sait combien le littéraire polyglotte et enthousiaste qu'il fut, m'apporta alors. Sa générosité, sa rigueur, son regard de sémioticien et son engagement complet dans tout ce qu'il entreprit, caractérisaient sa façon d'être, avec tous et à tout moment.

Les voix singulières d'Alexandre Amprimoz résonnent à travers le paysage littéraire canadien, au cœur de l'APFUCC, notamment dans la revue savante Voix plurielles qu'il fonda en 2004, et chez tous ceux, nombreux et de divers domaines, touchés par son érudition, son humour rabelaisien et, avant tout, sa fidélité. À mes yeux, Alexandre incarne celui qui s'incruste dans la vie immédiate et qui, à l'instar de Francis Ponge, Paul Éluard, Michel Deguy ou Paul Savoie, en livre ses observations, ses appréciations, ses critiques et ses cris de joie et d'amour :

une perle

rose

frissonne

écoute

et comprend (Changements de ton, 20)

Le savoir, la lucidité, l'ouverture et la sensibilité sont les qualités que l'on reconnaît au poète, à travers son œuvre et sa vie. Sa créativité, ainsi que son regard d'humaniste et de scientifique, captent les délices de ce monde :

monde aux cryptiques recettes

comme un champ de basilic

à perte d'odorat

quelques pauvres mots

dans la farine

immense imaginaire (Bouquet de signes, 20) 
Mais tempus fugit, et comme Saint-Denys Garneau, Alexandre vit intensément, passionnément et courageusement, car il en fait le constat tout simple :

et je n'ai pas le temps

d'autres avant moi sont tombés

le cœur sucé par un virus si lent

mon cœur à moi cet animal

frappe à n'en plus finir

pour briser les barreaux du sang (86)

Aussi les voix singulières d'Alexandre Amprimoz se font-elles entendre aujourd'hui encore et nous incitent à contempler la vie et la mort, sous toutes leurs apparences, et avec clarté devant notre vulnérabilité d'être humain.

Que nous puisions donc tous dans la plénitude du hic et nunc, comme Alexandre le fit, et que nous nous joignions à notre cher ami pour rompre l'os et sucer la substantifique moelle.

\section{Ouvrages cités}

Amprimoz, Alexandre. Changements de ton. Saint-Boniface : Plaines, 1981.

-----. Bouquet de signes. Sudbury : Prise de Parole, 1986. 